\title{
Flame Retardancy of Wood Products by Spreading Concentration and Impregnation Time of Flame Retardant ${ }^{1}$
}

\author{
Sohyun $\mathrm{PARK}^{2} \cdot$ Yeonjung $\mathrm{HAN}^{2}$ - Dong Won SON(D) ${ }^{2, \dagger}$
}

\begin{abstract}
The flame retardancy, such as carbonized length and area, of four plank type wood products by the spreading concentration and impregnation time of flame retardant were measured according to standard of the Nation Fire Agency in Republic of Korea. To measure the flame retardancy, Korean pine plywood, Japanese larch plywood, Japanese cypress planks, and perforated birch plywood boards were treated with self-development flame retardant by 300 and $500 \mathrm{~g} / \mathrm{m}^{2}$ spreading concentration and those were compared with control specimen. In general, the flame retardant performance of wood products improved as the spreading concentration of flame retardant increased. Except for Japanese larch plywood, there was no significant difference in the flame retardant performance by the spreading concentration. The flame retardant performance of perforated birch plywood board was positively correlated up to 60 minutes of impregnation time, but then gradually decreased. These results about the flame retardancy of wood products by spreading concentration and impregnation time were expected to be basic data for improving flame-retardant treated wood.
\end{abstract}

Keywords: flame retardant, spreading concentration, impregnation time, carbonized area, carbonized length

\section{INTRODUCTION}

Wood is a type of material that has aesthetic patterns and is easy to process into different shapes, causing it to be commonly used for a long time as interior/exterior building materials and furniture materials in residential spaces (Seo et al., 2015; Seo et al., 2016; Park et al., 2019). In general, consumers believe that wood is vulnerable to fire, and to address the issue, flame resistant agents and retardants are required to be developed. Wood, as a combustible material, is pyrolyzed to emit flammable gases to be ignited and burned, so it has been processed with anti-inflammatory agents to improve its combustion performance (Cha et al., 2011).

By definition, flame retardant refers to a chemical treatment to prevent continuous combustion or spread even when a combustible is ignited with a flame by restraining the combustion of the material through physical and chemical combinations with the material (Kim et al., 2014). Flame retardants may be classified into three types depending on their effects (Son, 1988). The first type is phosphorus compounds that restrain the generation of volatile substances created

${ }^{1}$ Date Received February 21, 2020, Date Accepted May 4, 2020

2 Division of Wood Utilization, Department of forest Products, National Institute of Forest Science, Seoul 02455, Republic of Korea

† Corresponding author: Dong Won SON (e-mail: dongwon12@korea.kr, ORCID: 0000-0002-5373-4126) 
when a flammable material is burned by alternating the pyrolysis process. The second type is an ammonia and boron compound that disrupts the air supply to combustion by coating the surface of the material or generating non-combustible gas around the material. The third is a halogenated compound, which is free radical obstruction agent that prevents flaming combustion from spreading.

In Korea, phosphorus compounds have often been used to fire-proof wooden cultural heritage sites (Kim et al., 2014). The flame retardants to preserve wooden cultural heritage sites must be certified by the Cultural Heritage Administration and the National Research Institute of Cultural Heritage for distribution. Each flame retardant has the different numbers of application and spreading concentrations. Generally, it is reported that the agents are applied 2 to 3 times and approximately $200-1,000 \mathrm{~g} / \mathrm{m}^{2}$ is applied each time. Commercial flame retardants consist of guanidine, phosphorus, HEDP (1-hydroxy ethylided-1, 1-diphosphonic acid), etc.

There is research in progress on the performance of flame retardants by application. One research found that a Korean red pine with $300 \mathrm{~g} / \mathrm{m}^{2}$ applied on it meets flame retardancy requirements in Korea. Application of $400 \mathrm{~g} / \mathrm{m}^{2}$ or more reportedly forms white deposit on the surface of the material (Seo et al., 2017). The Korean red pine that met the flame retardancy requirements with commercial flame retardants showed the carbonized length of 74-93 $\mathrm{mm}$ and the carbonized area of 2650-3970 $\mathrm{mm}^{2}$ (Seo et al., 2017; Choi et al., 2011).

Anti-inflammatory treatment methods include: application, which sprays or directly coats flame retardants on the surface of the wooden material, lining, which attach metal plates or other non-combustible materials, and impregnation, which penetrates flame retardants into the wooden material, depending on the characteristics of the combustible material (Kim and
Hyun, 2009; Cha et al., 2011). For wood materials and wooden products, the anti-inflammatory method of spraying or brushing flame retardants has been typically used after the materials or products are installed in the structures (Min et al., 2012), and research has been conducted on flame retardant impregnation times from 10 minutes up to 240 minutes to apply the impregnation method (Lim et al., 2008; Park et al., 2011; Kim et al., 2012; Kim et al., 2013). As it was reported that application of commercial retardants to a Korean red pine is more effective than impregnation (Choi et al., 2011), research is required to present appropriate treatment methods for different types of flame retardants and treated materials.

Combustion characteristics and flame retardancy of the material to be treated are critical factor in ignition prevention and fire suppression in the initial stage of a fire (Cha et al., 2011; Dobele et al., 2007; Lim et al., 2008). The flame retardancy methods may be separated by the direction and material of combustion, and metrics during combustion (Min et al., 2012). In Korea, flame retardancy is measured with the $45^{\circ}$ Meckel's burner method and the methylamine method.

The evaluation criteria of the performance based on the flame retardancy standards of the National Fire Agency (announcement no. 2019-2) include remaining flame time (time after the flame is removed until the combustion with flame stops), smoldering time (time after the flame is removed until the combustion without flame stops), carbonized area (area combusted by the flame), and carbonized length (the longest part of the combustion by the flame).

This research evaluated flame retardancy depending on the spreading concentration and impregnation time of phosphorus flame retardant by measuring carbonization length and area on four types of wooden materials based on the flame retardancy through the $45^{\circ}$ Meckel's burner method. 


\section{MATERIALS and METHODS}

\subsection{Testing materials}

The flame retardancy test used Korean pine (pinus koraiensis) plywood, Japanese larch (larix kaempferi) plywood, Japanese cypress (chameacyparis obtusa) planks, and perforated birch (betula platyphylla) plywood boards. The dimensions of the test specimens were $190 \mathrm{~mm}$ (width) $\times 290 \mathrm{~mm}$ (height) $\times 10 \mathrm{~mm}$ (thickness) as specified in the $45^{\circ}$ Meckel's burner method based on the flame retardancy standards of the National Fire Agency. The birch plywood boards were perforated with 980 holes per unit area $\left(\mathrm{m}^{2}\right)$. Four types of wooden products were used to measure flame retardancy by the spreading concentration of flame retardant, and perforated birch plywood boards to measure the performance by the impregnation time. Korean pine plywood, Japanese larch plywood, and Japanese cypress planks were selected because they are commonly used as interior finish and building materials in Korea (Lim et al., 2007; Song et al., 2015). Perforated birch plywood boards were selected because it is often used as a high-end finishing material and has superior strength and durability, and research was published to develop mass-productive objects through laser processing (Song, 2011). The test specimens were manufactured in sufficient quantities to repeat each process three times including untreated control groups. The manufactured specimens were humidified for 24 hours until they reached constant weight in a thermo-hygrostat under the conditions of $23^{\circ} \mathrm{C}$ and $50 \%$ humidity and retained for 2 hours in a desiccator with silica gel in it based on the flame retardancy standards before being used for testing. Refer to Table 1 for abbreviations related to the specimens used in the experiments.

\subsection{Flame retardant}

Phosphorus flame retardant was used for application and impregnation. The flame retardant was a phosphorus and boron compound that mainly consisted of diammonium phosphate $\left(\left(\mathrm{NH}_{4}\right)_{2} \mathrm{HPO}_{4}\right)$, sodium borate decahydrate $\left(\mathrm{Na}_{2} \mathrm{~B}_{4} \mathrm{O}_{7} \mathrm{H}_{2} \mathrm{O}\right)$, phosphoric acid $\left(\mathrm{H}_{3} \mathrm{PO}_{4}\right)$, and polyethylene glycol \#600 $\left(\mathrm{H}\left(\mathrm{CH}_{2} \mathrm{CH}_{2} \mathrm{O}\right) \mathrm{nOH}\right)$.

Table 1. Abbreviation list for specimens used in this study.

\begin{tabular}{cccc}
\hline Abbreviation & Samples & Flame retardant condition & Treatment method \\
\hline \hline A & Pinus koraiensis plywood & - & - \\
B & $300 \mathrm{~g} / \mathrm{m}^{2}$ & spreading \\
C & $500 \mathrm{~g} / \mathrm{m}^{2}$ & spreading \\
\hline D & Larix kaempferi plywood & - & - \\
E & & $300 \mathrm{~g} / \mathrm{m}^{2}$ & spreading \\
F & & $500 \mathrm{~g} / \mathrm{m}^{2}$ & spreading \\
\hline G & Chameacyparis obtusa louver & $300 \mathrm{~g} / \mathrm{m}^{2}$ & spreading \\
H & & $500 \mathrm{~g} / \mathrm{m}^{2}$ & spreading \\
I & & - & - \\
J & & $150 \mathrm{~g} / \mathrm{m}^{2}$ & spreading \\
K & Betula platyphylla perforated plate & $300 \mathrm{~g} / \mathrm{m}^{2}$ & spreading \\
L & & $500 \mathrm{~g} / \mathrm{m}^{2}$ & spreading \\
M & & $10,30,60,90,120,240 \mathrm{~min}$ & impregnation \\
\hline N & & & \\
\hline
\end{tabular}


This inorganic flame retardant is transparent without any color to expose the grain and patterns of the wood while maintaining the clean surfaces.

\subsection{Spreading and impregnation treatment}

The amount, method, and number of applications to analyze the flame retardancy with different spreading concentrations were determined based on the results of preceding research on commercial flame retardants (Son and Han, 2014; Seo et al., 2017). It was determined to apply $300 \mathrm{~g} / \mathrm{m}^{2}$ and $500 \mathrm{~g} / \mathrm{m}^{2}$ to the Korean pine plywood, Japanese larch plywood, and Japanese cypress planks and $150 \mathrm{~g} / \mathrm{m}^{2}, 300 \mathrm{~g} / \mathrm{m}^{2}$, and $500 \mathrm{~g} / \mathrm{m}^{2}$ to the perforated birch plywood boards. The application method involved brushing the flame retardant until the surfaces of the specimens were sufficiently soaked, drying them for 24 hours at a temperature of $23{ }^{\circ} \mathrm{C}$ and a $50 \%$ humidity, reapplying the agent, and repeating the process three times. The impregnation time of 10, 30, 60, 90, 120, and 240 minutes was also determined to analyze the flame retardancy with different impregnation times in flame retardant based on the conditions of a precedent study (Lim et al., 2008; Park et al., 2011, Kim et al., 2012; Kim et al., 2013) where the specimens were immersed for each treatment time in containers providing complete submergence of the specimens at a temperature of $23{ }^{\circ} \mathrm{C}$ and a humidity of $50 \%$. Refer to Table 2 for the flame-retardant treatment methods.

\section{4. $45^{\circ}$ MecKel's Burner Method}

The flame retardancy was assessed through the $45^{\circ}$ Meckel's burner method stated in Article 20-2 "Flame retardancy standards for flame-resistant objects (the National Fire Agency announcement no. 2019-2)" of the enforcement decree of the Act on Fire Prevention and Installation, Maintenance, and Safety Control of Fire-Fighting Systems. As shown in Fig. 1, the experiment used the $45^{\circ}$ combustion measuring device for the wood combustion, and butane gas as specified in KS M 2150 (liquefied petroleum gas) to fuel combustion. The specimens were secured on the support in the $45^{\circ}$ combustion measuring device and the flame from a heating device with a $65 \mathrm{~mm}$ length contacted the bottom in the center of the specimens. Each specimen was heated for two minutes and for the specimens that caught the flame, the heating device was removed two seconds after the specimen caught fire. The flame retardancy was measured through the remaining flame

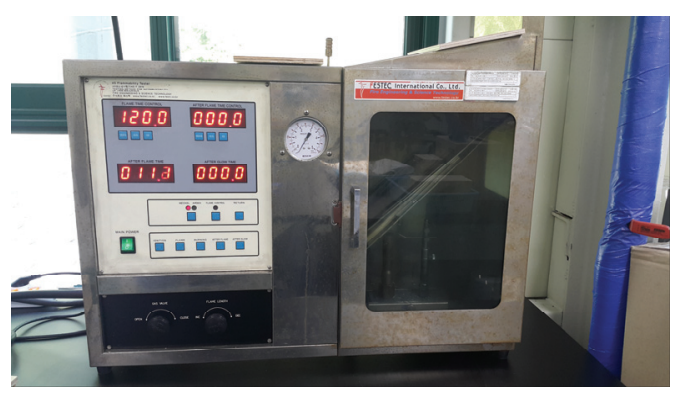

Fig. 1. The image of $45^{\circ}$ MecKel's burner tester.

Table 2. Treatment method of flame retardant.

\begin{tabular}{ll}
\hline Treatment method & \multicolumn{1}{c}{ Treatment condition } \\
\hline \hline \multirow{2}{*}{ Spreading method } & $\begin{array}{l}\text { The specimen was brushed with flame retardant liquid. And then the conditions of the } \\
\text { specimen and of the environment were the following: temperature } 23{ }^{\circ} \mathrm{C}, \text { relative humidity } \\
50 \% \text { during } 24 \mathrm{~h} . \text { The process was repeated three times. }\end{array}$ \\
\hline Impregnation method & $\begin{array}{l}\text { Each of specimens were immersed in flame retardant liquid for 10, 30, 60, 90, 120, 240 } \\
\text { min. The conditions of the specimen and of the environment were the following: temperature } \\
23{ }^{\circ} \mathrm{C}, \text { relative humidity } 50 \% .\end{array}$ \\
\hline
\end{tabular}


Flame Retardancy of Wood Products by Spreading Concentration and Impregnation Time of Flame Retardant

time (s), smoldering time (s), carbonized length ( $\mathrm{mm})$ and carbonized area $\left(\mathrm{mm}^{2}\right)$ of each specimen. Refer to the "flame retardancy standards for flame-resistant objects" for definitions of each anti-inflammatory metrics. The standards require the remaining flame time (after the flame of the burner is removed until the combustion with flame stops) to be 10 seconds or shorter, the smoldering time (after the flame of the burner is removed until the combustion without flame stops, excluding the time that the flame remains) to be 30 seconds or shorter, the area carbonized by the flame to be $5,000 \mathrm{~mm}^{2}$ or smaller, and the carbonized length (the length carbonized by the flame) to be 200 $\mathrm{mm}$ or shorter.

\section{RESULTS and DISCUSSION}

\subsection{Flame retardant performance of wood products treated with different spreading concentrations}

Table 3 and Fig. 2-5 show the remaining flame time, the smoldering time, the carbonized length, and the carbonized area measured by the $45^{\circ}$ Meckel's burner method with different spreading concentrations applied to the four type of wood products. Regardless of application of the flame retardant, both the remaining flame time and the smoldering time were $0 \mathrm{sec}-$ onds, meeting the flame-retardant performance standards. However, the topic requires further study as smoke poses a bigger threat than continuous combustion in the event of a fire (White, 2000).

The test of untreated specimens showed a carbonized length of 127.8-176.2 $\mathrm{mm}$ and the treated ones showed a length of 81.1-116.5 $\mathrm{mm}$, satisfying the flame-retardant performance standards of $200 \mathrm{~mm}$. The carbonized areas of the untreated specimens ranged from 7461 to $8987 \mathrm{~mm}^{2}$, failing to meet the standards requirement of $5000 \mathrm{~mm}^{2}$, while the testedspecimens treated with the flame retardant, except for the ones with spreading concentration of $150 \mathrm{~g} / \mathrm{m}^{2}$, showed up to $4019 \mathrm{~mm}^{2}$ of the area, which meets the standards.

For Japanese larch plywood, the carbonized length and the carbonized area decreased from $100.9 \mathrm{~mm}$ and $4019 \mathrm{~mm}^{2}$ to $79.6 \mathrm{~mm}$ and $2848 \mathrm{~mm}^{2}$ as the spreading concentration increased from $300 \mathrm{~g} / \mathrm{m}^{2}$ to $500 \mathrm{~g} / \mathrm{m}^{2}$. On the other hand, the preceding study using a com

Table 3. Flame retardancy of wood products treated with difference spreading concentration.

\begin{tabular}{ccccc}
\hline \multirow{2}{*}{ Sample } & Remaining flame time $(\mathrm{sec})$ & Smoldering time $(\mathrm{sec})$ & Carbonized area $\left(\mathrm{mm}^{2}\right)$ & Carbonized length $(\mathrm{mm})$ \\
\cline { 2 - 5 } & less than $10 \mathrm{sec}$ & less than $30 \mathrm{sec}$ & less than $5000 \mathrm{~mm}^{2}$ & less than $200 \mathrm{~mm}$ \\
\hline \hline A & 0 & 0 & 8949 & 158.6 \\
B & 0 & 0 & 3286 & 87.0 \\
C & 0 & 0 & 3184 & 81.1 \\
D & 0 & 0 & 8987 & 164.6 \\
E & 0 & 0 & 4019 & 100.9 \\
F & 0 & 0 & 2848 & 79.6 \\
G & 0 & 0 & 8829 & 84.4 \\
H & 0 & 0 & 2506 & 81.8 \\
I & 0 & 0 & 2456 & 127.8 \\
J & 0 & 0 & 7461 & 116.5 \\
K & 0 & 0 & 5151 & 95.1 \\
L & 0 & 0 & 3694 & 86.1 \\
M & 0 & 0 & 3004 & \\
\hline
\end{tabular}




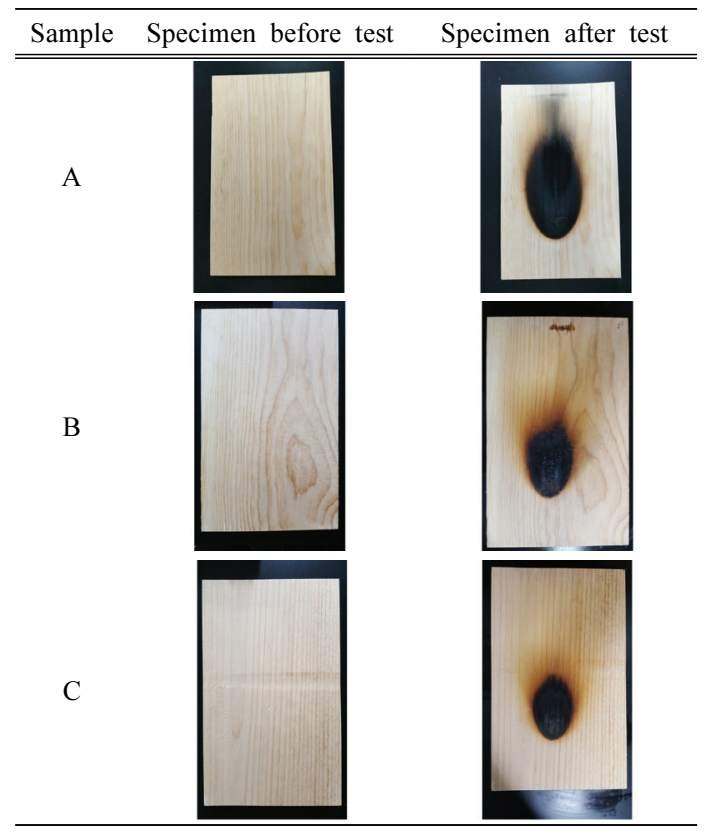

Fig. 2. Result of flame retardancy test for Pinus koraiensis plywood treated with difference spreading concentration.

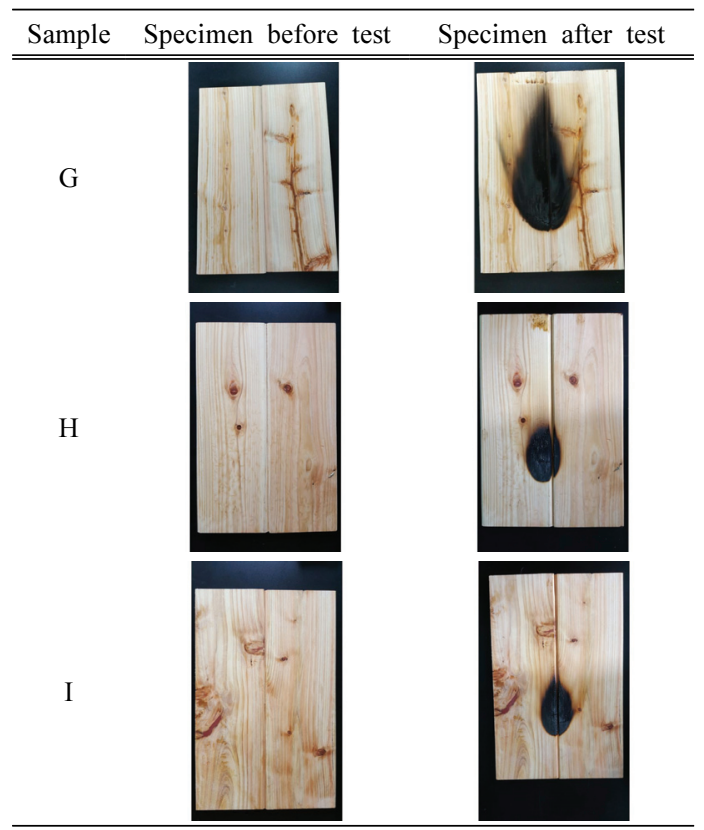

Fig. 4. Result of flame retardancy test for Chameacyparis obtusa plywood treated with difference spreading concentration.

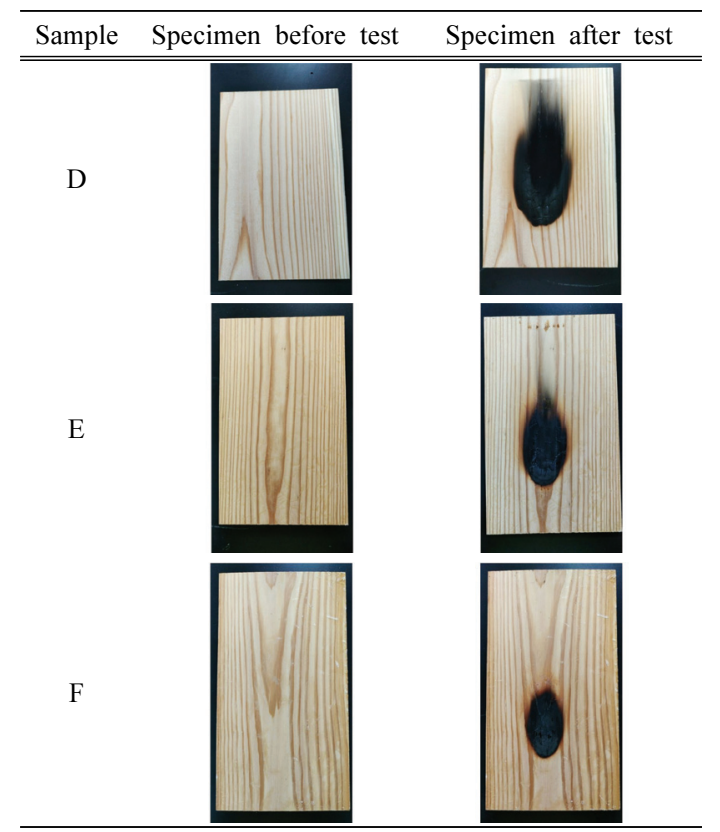

Fig. 3. Result of flame retardancy test for Larix kaempferi plywood treated with difference spreading concentration.

mercial flame retardant containing guanidine and polyphosphate (Ho and Seong, 2004) found that even the spreading concentration of $500 \mathrm{~g} / \mathrm{m}^{2}$ did not meet the flame retardant performance standards. This demonstrates that the phosphorus flame retardant is more effective for Japanese larch plywood and perforated birch plywood boards. It is known that effective flame retardant first decomposes and carbonizes cellulose, which is a main ingredient of wood, at a lower temperature $\left(<300{ }^{\circ} \mathrm{C}\right)$ and generates fewer volatile substances (Park et al., 2012).

The perforated birch plywood boards showed the carbonized length and area of $116.5 \mathrm{~mm}$ and 5151 $\mathrm{mm}^{2}$ with $150 \mathrm{~g} / \mathrm{m}^{2}$ of the agent applied, which does not live up to the standards, however, as the spreading concentration increased to $300 \mathrm{~g} / \mathrm{m}^{2}$, the length and the area were significantly reduced to $95.1 \mathrm{~mm}$ and $3694 \mathrm{~mm}^{2}$, reaching the flame retardant performance standards. Although the carbonized length and the 
Flame Retardancy of Wood Products by Spreading Concentration and Impregnation Time of Flame Retardant

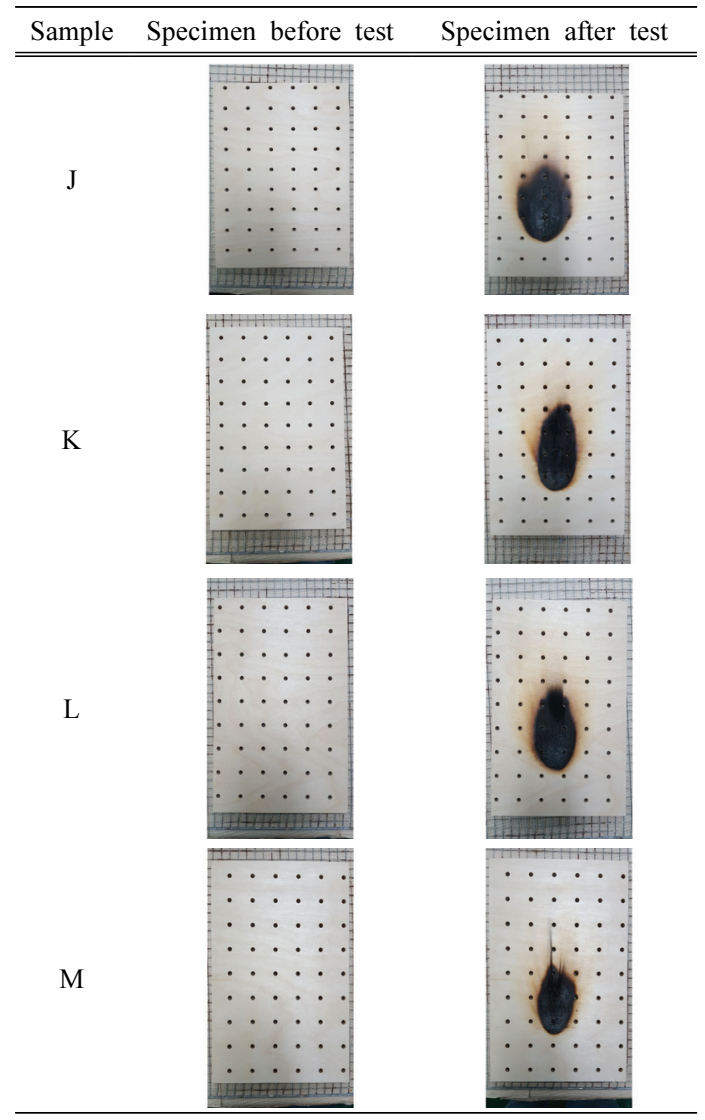

Fig. 5. Result of flame retardancy test for Betula platyphylla plywood treated with difference spreading concentration.

carbonized area tend to decrease as the spreading concentration increases, improving the flame-retardant performance as mentioned above, Table 3 demonstrates that the tendency is not pronounced with Korean pine plywood and Japanese cypress planks. This is consistent with the outcomes of the previous study, where an increase in the concentration of the flame retardant did not significantly affect the carbonized area in coniferous trees (Park et al., 2012). It is thought that the difference between the species of tress is caused by the application, which only spreads on the surface of wood.

The performance of the flame retardant used in this study satisfied the standards set by the National Fire Agency with the spreading concentration of common commercial flame retardants. However, different wood products and tree species shows different effect of the improvement in the flame retardant's performance as the spreading concentration increases, implying the necessity of additional study on the species of trees. Since the perforated birch plywood boards with 150 $\mathrm{g} / \mathrm{m}^{2}$ applied exceeded the standards, a study should be conducted to verify the cost-effective spreading concentration that passes the flame retardant performance standards with $300 \mathrm{~g} / \mathrm{m}^{2}$ or less for the industrial use of flame retardants.

\subsection{Flame retardant performance of perforated Betula Platyphylla plywood boards treated with different impregnation times}

Table 4 and Fig. 6 show the remaining flame time, the smoldering time, the carbonized length and the carbonized area measured for perforated birch plywood boards through the $45^{\circ}$ Meckel's burner method with different impregnation times.

Regardless of the impregnation time, both the remaining flame time and the smoldering time were 0 seconds. All the test specimens treated with impregnation met the standards of the carbonized length of $200 \mathrm{~mm}$ and the carbonized area of $5000 \mathrm{~mm}^{2}$. The impregnation time and the flame retardant's performance showed a positive correlation for the first $60 \mathrm{mi}-$ nutes, but the curve grew flatter gradually after that. After 90 minutes into the impregnation, the carbonized length and the carbonized area rose. This demonstrates that little flame retardant penetrates into wood after 60 minutes, which is consistent with the preceding study (Kim et al., 2013), where the weight of imported sawn wood hardly increased after the first 60 minutes of impregnation. The flame-retardant performance of birch plywood boards with different impregnation 
Table 4. Flame retardancy of Betula platyphylla perforated plate treated with difference impregnation time

\begin{tabular}{|c|c|c|c|c|}
\hline \multirow{2}{*}{ Sample } & Remaining flame time (sec) & Smoldering time (sec) & Carbonized area $\left(\mathrm{mm}^{2}\right)$ & Carbonized length $(\mathrm{mm})$ \\
\hline & less than $10 \mathrm{sec}$ & less than $30 \mathrm{sec}$ & less than $5000 \mathrm{~mm}^{2}$ & less than $200 \mathrm{~mm}$ \\
\hline $\mathrm{N}-10 \mathrm{~min}$ & 0 & 0 & 3576 & 100.5 \\
\hline $\mathrm{N}-30 \mathrm{~min}$ & 0 & 0 & 3341 & 90.6 \\
\hline $\mathrm{N}-60 \mathrm{~min}$ & 0 & 0 & 2673 & 81.8 \\
\hline $\mathrm{N}-90 \min$ & 0 & 0 & 2604 & 78.5 \\
\hline $\mathrm{N}-120 \min$ & 0 & 0 & 2781 & 80.1 \\
\hline $\mathrm{N}-240 \mathrm{~min}$ & 0 & 0 & 2730 & 83.3 \\
\hline Sample & Impregnation time & Specimen after test & Impregnation time & Specimen after test \\
\hline & $10 \mathrm{~min}$ & 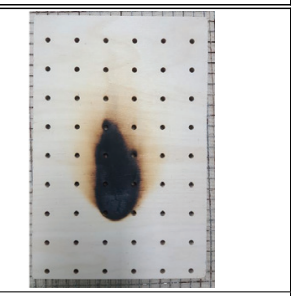 & $90 \mathrm{~min}$ & 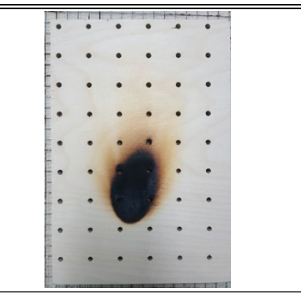 \\
\hline $\mathrm{N}$ & $30 \mathrm{~min}$ & 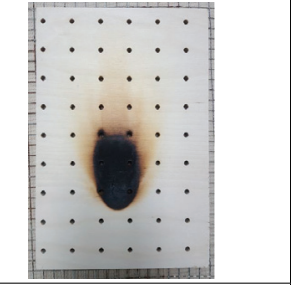 & $120 \mathrm{~min}$ & 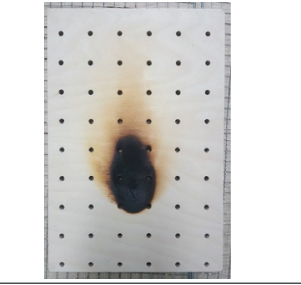 \\
\hline & $60 \mathrm{~min}$ & 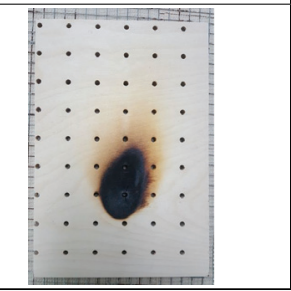 & $240 \mathrm{~min}$ & 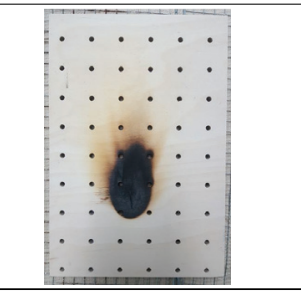 \\
\hline
\end{tabular}

Fig. 6. Result of flame retardancy test for Betula platyphylla perforated plate treated with difference impregnation time.

times in this study was similar to a previous study that found a significant improvement of the flame-retardant performance after 30 minutes of impregnation for Korean ash trees, maple trees, and oaks (Lim et al., 2008). However, considering a preceding study that resulted in arelatively low flame-retardant performance with the carbonized length and area of $105.0 \mathrm{~mm}$ and $4750 \mathrm{~mm}^{2}$ respectively after pine wood specimens were immersed for 72 hours, it seems that the optimal impregnation time depends on the species of the tree. An earlier study on the flame retardant's performance after poplar was immersed in APP (ammonium polyphosphate) for 10 minutes concluded thatammonia and water generated by decomposed APP dilute combustibles to enhance the performance (He, 2016). Therefore, it is believed that diammonium phosphate 
used in this study was pyrolyzed to generate ammonia and water, raising the performance of perforated birch plywood boards.

The flame retardant's performance of the perforated birch plywood boards met the performance standards of the National Fire Agency after 10 minutes of impregnation, but the appropriate impregnation time was determined to be 60 minutes. In addition, further studies on a variety of tree species and wood products are required to verify the most effective impregnation time for popular wood materials in Korea.

\section{CONCLUSION}

This study analyzed the flame retardancy with different spreading concentrations and impregnation times of four types of planks by measuring the remaining flame time, the soldering time, the carbonized length, and the carbonized area and concludes the following:

1) Flame retardant performance testing resulted in performance improvement through decreased carbonized length and area with increased spreading concentration of flame retardant on Japanese larch plywood and perforated birch plywood boards, but the tendency was not distinct for Korean pine plywood and Japanese cypress planks; and

2) Flame retardant performance testing showed a positive correlation between the impregnation time and the flame retardance performance until 60 minutes into impregnation of perforated birch plywood boards, but the curve was gradually flattened after that time.

This study verified the flame retardancy of the four types of wood plates and as a result, phosphorus flame retardant effectively prevented flames for Japanese larch plywood and perforated birch plywood boards, and the best impregnation time for perforated birch plywood boards was 60 minutes.

\section{REFERENCES}

Cha, J.M., Hyun, S.H., Kim, I.B., Yoon, M.O. 2011. A study on the flame retardant performance of $\mathrm{mdf}$ wood according to flame retardant treatment method. Journal of Korean Institute of Fire Science and Engineering 25(6): 146-155.

Choi, J.M., Ro, H.S., Jin, Y.H. 2011. A study on combustion characteristics of flame retardant treated Pinus Densiflora. Journal of Korean Institute of Fire Science 25(3): 244-251.

Dobele, G., Urbanovich, I., Zhurins, A., Kampars, V., Meier, D. 2007. Application of analytical pyrolysis for wood fire protection control. Journal of Analytical and Applied Pyrolysis 79(1-2): 47-51.

He, X., Li, X.J., Zhong, Z., Mou, Q., Yan, Y., Chen, H., Liu, L. 2016. Effectiveness of impregnation of ammonium polyphosphate fire retardant in poplar wood using microwave heating. Fire and materials 40(6): 818-825.

Ho, C.S., Seong, H.G. 2004. Thermal degradation of wood treated with guanidine compounds in air flammability study. Journal of Thermal Analysis and Calorimetry 75: 221-232.

Kim, C.G., Park, C.W., Yoon, T.H., Lim, N.G. 2013. Characteristics of flame retardant and mothproof conversation of Microwave heated wood. Journal of the Korean Wood Science and Technology 41(3): 234-246.

Kim, D.W., Kim, C.W., Han, S.H., Chung, Y.J., Han, G.S. 2014. Flame retardant treatment's effects and detection method on wooden buildings' pigment layer (Dan-cheong). Journal of the Korean Wood Science and Technology 42(4): 393-406.

Kim, H.W., Jung G.S., Jung R.H., Lee, B.K. 2012. Development of fire proof clothes for the multiplex available premises fire. Journal of Korea Society and Harzard Mitigation. 12(3): 211-215. 
Kim, I,B., Hyun, S.H. 2009. A study on the flame retardant performance and toxicity of the painting wood painted with flame retardant solution. Journal of Korean Institute of Fire Science 23(5): 66-71.

Lim, B.A., Kim, J.C., Kim, S.Y., Son, Y.S., Kim, K.H., Sun, Y.Y., Kang, Y.S. 2007. Variations of VOC emission rates from indoor wallboard with elapsed time. Proceeding of the $45^{\text {th }}$ Meeting of Korean Society for Atmospheric Environment.

Lim, N.G., Her, J.W., Park, C.W. 2008. An experimental study on flame resistant performance by flame resistant method and agents. Journal of Korean Institute of Building Construction 8(6): 117-122.

Min, S.H., Sun, J.S., Kim, S.C., Choi, Y.M., Lee, S.K. 2012 A study on fire performance evaluation of EIFS on anti-flaming finish by cone calorimeter test. Journal of Korean Institute of Fire Science 26(3): 106-111.

Park, H.J., Wen, M., Cheon, S.H., Hwang, J.W., Oh, S.W. 2012. Flame retardnat performance of wood treated with flame retardant chemicals. Journal of the Korean Wood Science and Technology 40(5): 311-318.

Park, J.E., Yoon, S.M., Choi, Y.S., Hwang, W.J., Son, D.W. 2018. Performance evaluation of domestic flame retardant perforated plate, JunJu, Republic of Korea, Proc. of 2018 the Korean society of wood science and technology annual meeting, April, 1: 68-68.

Park, S., Han, Y., Son, D.W. 2019. Analysis of combustion characteristics of five domestic species. Journal of the Korea Furniture Society 30(4): 303-311.

Park. C.W., Her, J.W., Lim, N.G. 2011. The liquid flame proofing agent's permeating effect of wood using microwave. Journal of the Korea Institute of Building Construction 11(3): 256-264.

Seo, H.J., Kang, M.R., Park, J.E., Son, D.W. 2016. Combustion characteristics of useful imported woods. Journal of the Korean Wood Science and Technology 44(1): 19-29.

Seo, H.J., Kang, M.R., Son, D.W. 2015. Combustion properties of woods for indoor use (II). Journal of the Korean Wood Science and Technology 43(4): 478-485.

Seo, H.J., Kim, N.K., Jo, J.M., Lee, M.C. 2017. Analysis on the Flame-Retardant Performance and Hazards in Gas Products for Water-Soluble Flame-RetardantChemicals Treated Woods. Journal of Korea Society and Harzard Mitigation 17(4): 173-179. Son, D.W., Han, G.S. 2014. Evlauation methods of flame retarants for wooden cultural properties. Journal of the Korean Wood Science and Technology 42(5): 590-596.

Son, Y.S. 1988. Trace back on the past of flame retardant treatment and countermeasure in the Korea. Journal of Chemistry of Fire Prevention 2(2): 31-41.

Song, Y.J., Jung, H.J., Lee, I.H., Hong, S.I. 2015. Performance evaluation of bending strength of curved composite glulams made of Korean white pine. Journal of the Korean Wood Science and Technology 43(4): 463-469.

Song, Y.S. 2011. A study on the furniture design applied with the characteristic of mother-of-pearl and Birch plywood. Journal of the Korea Furniture Society 22(4): 245-251.

White, R.H. 2000. Charring rate of composite timber products. The proceedings of Wood and Fire Safety 2000, Part 1, 4th International Scientific Conference, May, pp. 14-19. 


\title{
APPENDIX
}

\author{
(Korean Version)
}

\section{방염제의 도포량과 침지시간 차이에 따른 목재제품의 방염성능}

초록 : 4종의 판상형 목재제품의 방염제 도포량과 침지시간에 따른 방염성능을 분석하기 위하여 소방청의 방염성능기준에 따라 목재제품의 탄화길이와 탄화면적을 측정하였다. 잣나무 합판, 낙엽송 합판, 편백 판재, 타공처리된 자작나무 합판에 자체 개발된 방염제를 각각 $300,500 \mathrm{~g} / \mathrm{m}^{2}$ 씩 도포하고 방염처리되지 않은 시험편과 비교하였다. 일반적으로 방염제의 도포량이 증가함에 따라 탄화길이와 탄화면적이 감소하여 방염성능이 증가하는 경향을 나타냈으나, 낙엽송 합판을 제외하고 탄화길이와 탄화면적의 감소량이 크지 않았다. 타공처리된 자작나무 합판의 침지시간에 따른 방염성능은 60 분의 침지시간까지 양의 상관관 계를 나타냈으나, 그 이후 점차 완만해지는 경향을 보였다. 방염제의 도포량과 침지시간에 따른 목재제품의 방염성능은 추후 방염성능 기준에 맞는 불연·준불연 목재의 생산을 위한 기초자료로 이용될 것으로 기대된다.

\section{1. 서 론}

목재는 심미적인 무늬를 지니며, 다양한 형태로의 가공이 용이한 장점을 갖는 재료로써 예로부터 건축용 내·외장재, 가구재 등으로 주거공간에 이용되어 왔다(Seo et al., 2015; Seo et al., 2016; Park et al., 2019). 일반적으로 소비자들은 목재가 화재에 취약하다는 인식을 지니고 있으며, 이러한 문제의 해결을 위하여 방염제와 난연제 등을 개발이 필요한 상황이다. 목재는 연소성 물질로써 화재에 노출될 경우, 열분해되어 가연성 가스를 배출하고 착화되어 연소하기 때문에 목재의 연소성능을 개선하기 위한 방법으로 방염제를 활용한 방염처리가 진행되어왔다(Cha et al., 2011).

방염제의 사전적 의미는 가연성 물질에 불꽃을 점화해도 스스로 계속 연소되거나 번지지 않도록 하기 위한 화학적 처리약품이 며, 재료와의 물리 - 화학적 결합을 통해 재료의 연소를 억제시킨다(Kim et al., 2014). 방염제는 작용 효과에 따라 3가지 유형으 로 분류할 수 있다(Son, 1988). 첫 번째, 가연성 재료의 연소시 열분해 과정을 변화시킴으로써 연소시 발생하는 휘발성 물질의 생성을 억제하는 인 화합물계, 두 번째, 가연성 재료의 표면을 코팅하거나 재료 주위에 불연가스를 발생시켜 연소 중 산소 공급을 방해하는 암모니아 화합물계 또는 붕소화합물, 세 번째, 불꽃 연소의 전파를 방지하는 자유라디칼 방해제인 할로겐 화합물계이다.

국내에서는 목조문화재의 보존을 위한 방염처리에 주로 인계 화합물 방염제가 이용되어왔다(Kim et al., 2014). 목조문화재의 보존을 위한 방염제들은 문화재청과 국립문화재연구소에서 인증을 받아 유통되고 있다. 각각의 방염제는 종류 및 특성에 따라 도포횟수와 도포량을 다르게 적용하는데, 일반적으로 도포횟수 2 3회이며 1회 도포량은 약 200 1000 g/ $\mathrm{m}^{2}$ 으로 보고된다. 상용되는 방염제의 구성성분은 구아니딘계, 인계, HEDP(1-Hydroxy Ethylided-1, 1-Diphosphonic acid)계 등이 있다.

방염제의 도포량에 따른 방염성능에 대한 연구가 진행되고 있다. 소나무에 방염제 $300 \mathrm{~g} / \mathrm{m}^{2}$ 를 도포한 경우에 국내 방염성능기 준을 만족한 연구가 있으며, 이 때 방염제를 $400 \mathrm{~g} / \mathrm{m}^{2}$ 이상 도포할 경우 재료의 표면에 백색 침전물이 형성된다고 보고되었다 (Seo et al., 2017). 상용 방염제를 소나무에 도포하여 방염성능기준을 만족한 연구에서 측정된 탄화길이는 74 93 mm의 범위였 으며, 탄화면적은 2650 3970 $\mathrm{mm}^{2}$ 의 범위였다(Seo et al., 2017; Choi et al., 2011).

방염처리 방법은 가연성 재료의 특성에 따라 상이하나 방염제를 목재 표면에 뿌리거나 직접 도장하는 도포법, 금속판이나 기타 불연재를 목재표면에 부착시키는 라이닝(lining)법, 방염제를 목재 내부까지 침투시키는 함침법(impregnation) 등 세 가지 로 나눌 수 있다(Kim and Hyun, 2009; Cha et al., 2011). 일반적으로 목재와 목재제품에 대한 방염처리는 건축물에 시공된 이후 방염제를 스프레이 코팅하거나 붓으로 칠하는 방식이 이용되어 왔으며(Min et al., 2012), 함침법을 적용하기 위하여 방염제에 대한 침지시간을 최소 10 분에서 최대 240분으로 적용하는 연구들이 수행되었다(Lim et al., 2008; Park et al., 2011; Kim et al., 2012; Kim et al., 2013). 소나무에 상용 방염제를 처리하는 경우 함침처리에 비하여 도포처리의 효과가 우수하다고 보고되어(Choi et al., 2011), 방염제의 종류와 처리 재료에 따른 적합한 처리방법을 제시하는 연구가 필요한 상황이다.

방염처리 대상물의 연소특성과 방염성능은 화재 초기의 착화방지 및 화재 발전의 억제를 위한 중요 요소이다(Cha et al., 2011; Dobele et al., 2007; Lim et al., 2008). 방염성능을 측정하는 방법은 연소의 진행방향, 연소원료 및 연소 중 측정항목에 따라 구분할 수 있다(Min et al., 2012). 국내에서는 방염성능의 측정방법으로 버너법 중 $45^{\circ}$ 멕켈버너법과 메틴아민법을 채택하고 있다. 
소방청의 방염성능기준(소방청고시 제2019-2호)에 의거한 방염성능 평가항목은 잔염시간(불꽃을 제거한 때부터 불꽃을 올리 며 연소하는 상태가 그칠 때까지의 시간), 잔신시간(불꽃을 제거한 때부터 불꽃을 올리지 아니하고 연소하는 상태가 그칠 때까지의 시간), 탄화면적(불꽃에 의하여 연소 되어진 면적), 탄화길이(불꽃에 의하여 연소 되어진 부분 중 가장 긴 부분)의 항목으로 구성되어 있다.

본 연구에서는 인계 방염제의 도포량 및 침지처리 시간에 따른 방염성능을 측정하였다. 4 종의 목재제품을 대상으로 $45^{\circ}$ 멕켈버너법을 적용하여 소방청의 방염성능기준에 따라 탄화길이와 탄화면적으로 측정하였다.

\section{2. 재료 및 방법}

\subsection{Testing materials}

방염성능 시험을 위하여 잣나무(Pinus koraiensis) 합판, 낙엽송(Larix kaempferi) 합판, 편백나무(Chameacyparis obtusa) 판재, 타공처리된 자작나무(Betula platyphylla) 합판을 이용하였다. 시험편은 소방청의 방염성능기준의 $45^{\circ}$ 멕켈버너법에 제시 된 것과 같이 가로 $190 \mathrm{~mm} \times$ 세로 $290 \mathrm{~mm} \times$ 두께 $10 \mathrm{~mm}$ 로 제조하였다. 자작나무 합판에는 단위면적당 $\left(\mathrm{m}^{2}\right)$ 980개의 공구를 갖도록 타공처리를 하였다. 방염제의 도포량에 따른 방염성능의 측정에 4종의 목재제품이 이용되었으며, 침지시간에 따른 방염성능의 측정에 타공처리된 자작나무 합판이 이용되었다. 잣나무 판재, 낙엽송 판재, 편백나무 판재는 실내 내장재로 주로 사용되는 국내 주요 수종이며 건축재료로 많이 사용되고 있는 것을 근거로 선정되었다(Lim et al., 2007, Song et al., 2015). 자작나무 합판은 고급마감재로 주로 사용하며 강도와 내구성이 뛰어난 장점이 있으며 레이저 가공하여 양산적인 소품을 개발하 는 연구가 보고된바 있어(Song, 2011) 타공처리된 자작나무 합판을 시험편으로 선정하였다. 시험편은 비교를 위한 무처리 대조군을 포함하여 처리방법별 3 반복을 위한 수량으로 제조되었다. 제조된 시험편은 방염성능기준에 의거하여 항량이 될 때까지 온도 $23^{\circ} \mathrm{C}$, 습도 $50 \%$ 조건의 항온항습기에서 항량에 도달할 때까지 24 시간 조습처리한 후 실리카 겔을 넣은 데시케이터 안에서 2 시간 동안 넣어 둔 후 실험에 사용하였다. 실험에 사용된 시험편의 약어 표현을 Table 1에 정리하였다.

\subsection{Flame retardant}

인계 방염제를 이용하여 도포 및 침지처리를 수행하였다. 방염제는 인, 붕소계 화합물로써 주요 성분은 Diammonium phosphate $\left(\left(\mathrm{NH}_{4}\right)_{2} \mathrm{HPO}_{4}\right)$, Sodium borate decahydrate $\left(\mathrm{Na}_{2} \mathrm{~B}_{4} \mathrm{O}_{7} \mathrm{H}_{2} \mathrm{O}\right)$, Phosphoric acid $\left(\mathrm{H}_{3} \mathrm{PO}_{4}\right)$, Polyethylene glycol

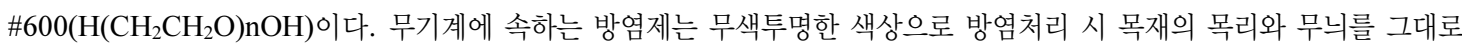
노출시키며 표면을 깨끗한 상태로 보관할 수 있는 장점이 있다.

\subsection{Spreading and impregnation treatment}

방염제의 도포량 차이에 따른 방염성능을 분석하기 위한 도포량, 도포방법, 도포횟수는 상용 방염제에 대한 선행연구의 결과(Son and Han 2014; Seo et al., 2017)를 바탕으로 결정하였다. 도포량은 잣나무 합판, 낙엽송 합판, 편백나무 판재의 경우 $300,500 \mathrm{~g} / \mathrm{m}^{2}$ 으로 결정하고, 타공처리된 자작나무 합판의 경우 $150,300,500 \mathrm{~g} / \mathrm{m}^{2}$ 으로 결정하였다. 도포처리 방법은 시험편의 표면이 충분히 젖을 때까지 붓을 이용해 방염제를 바른 다음 온도 $23^{\circ} \mathrm{C}$, 습도 $50 \%$ 조건에서 24 시간 건조 후 다시 약제를 바르는 방법으로 3 회 반복하였다. 방염제의 침지시간에 따른 방염성능을 분석하기 위한 침지시간의 결정도 선행연구 (Lim et al., 2008; Park et al., 2011; Kim et al., 2012; Kim et al., 2013)의 조건을 인용하여 10, 30, 60, 90, 120, 240분으로 선정하였으며 온도 $23{ }^{\circ} \mathrm{C}$, 습도 $50 \%$ 환경에서 시험편이 충분히 잠길 정도의 용기 내에서 각각의 처리시간별로 침지시켰다. 이와 같은 방염제 처리방법을 Table 2에 정리하였다.

\section{4. $45^{\circ}$ MecKel's burner method}

방염성능평가는 화재예방, 소방시설 설치유지 및 안전관리에 관한 법률 시행령 제 20 조 제 2 항 “방염대상물의 방염성능기준(소 방청고시 제2019-2호)"에 제시된 45 맥켈버너법을 적용하여 수행되었다. 본 실험에서 사용한 목재 연소시험 장치는 Fig. 1 과 같이, $45^{\circ}$ 연소측정장치를 사용하였으며 연소를 위한 연료는 KS M 2150(액화석유가스)에 제시된 부탄가스를 이용하였다. 시험편은 $45^{\circ}$ 연소측정 장치 내의 받침대에 고정시킨 후 $65 \mathrm{~mm}$ 의 길이인 가열장치의 불꽃이 시험편의 중앙부 하단에 접하도록 하였다. 가열처리는 각 시험편에 대하여 2 분간 진행하였으며 가열 중에 착염되는 시험편은 착염이 발생한 2 초 후에 가열장치를 제거하였다. 각 시험편에 대하여 잔염시간 $(\mathrm{s})$, 잔신시간 $(\mathrm{s})$, 탄화길이 $(\mathrm{mm})$, 탄화면적 $\left(\mathrm{mm}^{2}\right)$ 의 방염성능을 측정하였다. "방염대상 물의 방염성능기준”에 각각의 방염성능에 대하여 정의되어 있다. 버너의 불꽃을 제거한 때부터 불꽃을 올리며 연소하는 상태가 
Flame Retardancy of Wood Products by Spreading Concentration and Impregnation Time of Flame Retardant

그칠 때까지의 시간을 의미하는 잔염시간이 10 초 이내, 버너의 불꽃을 제거한 때부터 불꽃을 올리지 아니하고 연소하는 상태가 그칠 때까지의 시간(잔염이 생기는 동안의 시간은 제외)을 의미하는 잔신시간이 30 초 이내, 불꽃에 의해 탄화된 면적이 5000 $\mathrm{mm}^{2}$ 이내, 불꽃에 의해 탄화된 길이를 의미하는 탄화길이가 $200 \mathrm{~mm}$ 이내이어야 한다.

\section{3. 결과 및 고찰}

3.1. Flame retardant performance of wood products treated with difference spreading concentration

목재제품 4종에 대한 방염제의 도포량 차이에 따른 $45^{\circ}$ 맥켈버너법을 이용하여 목재제품의 4종에 대한 도포량 차이에 따른 잔염시간, 잔신시간, 탄화길이, 탄화면적을 $45^{\circ}$ 맥켈버너법을 이용하여 측정한 결과를 Table 3, Figs. 2 5에 제시하였다.

잔염시간과 잔신시간은 방염제의 유무와 상관없이 모두 0 초로 측정되었다. 잔염시간과 잔신시간은 방염처리와 무관하게 방염성능기준을 모두 만족하였으나, 화재 발생시 연소의 지속보다 연기의 발생이 더 큰 문제가 될 수 있으므로 이에 대한 추가적인 연구가 필요할 것으로 판단된다(White, 2000).

탄화길이는 방염처리 되지 않은 시험편에서 $127.8 \sim 176.2 \mathrm{~mm}$ 의 범위, 방염처리된 시험편에서 $81.1 \sim 116.5 \mathrm{~mm}$ 의 범위로 측정되어 방염성능기준인 $200 \mathrm{~mm}$ 를 만족하였다. 탄화면적은 방염처리되지 않은 시험편에서 7461 8987 mm²의 범위로 방염성 능기준인 $5000 \mathrm{~mm}^{2}$ 을 만족하지 못한 반면에, 도포량 $150 \mathrm{~g} / \mathrm{m}^{2}$ 을 제외한 방염처리된 시험편에서는 최대 $4019 \mathrm{~mm}^{2}$ 로 측정되어 방염성능기준을 만족하였다.

방염제의 도포량 차이에 따른 탄화길이와 탄화면적은 낙엽송 합판에서 도포량이 $300 \mathrm{~g} / \mathrm{m}^{2}$ 에서 $500 \mathrm{~g} / \mathrm{m}^{2}$ 으로 증가함에 따라 각각 $100.9 \mathrm{~mm}$ 와 $4019 \mathrm{~mm}^{2}$ 에서 $79.6 \mathrm{~mm}$ 와 $2848 \mathrm{~mm}^{2}$ 로 감소하였다. 구아니딘과 폴리포스페이트로 구성된 상용방염제를 사용한 선행연구와 비교했을 때(Ho and Seong, 2004), $500 \mathrm{~g} / \mathrm{m}^{2}$ 의 도포량에서도 방염성능기준을 만족하지 못한 것으로 보고된 바 있다. 결과적으로 인계 방염제는 낙엽송 판재와 타공처리된 자작나무 합판에서 우수한 방염성능을 확인하였다. 우수한 방염제는 낮은 온도 $\left(<300^{\circ} \mathrm{C}\right)$ 에서 목재의 주요 성분인 셀룰로오스를 먼저 분해하며 탄화시키고 휘발성 물질을 적게 생성하는 것으로 알려져 있다(Park et al., 2012).

타공처리된 자작나무 합판에서 탄화길이와 탄화면적은 도포량이 $150 \mathrm{~g} / \mathrm{m}^{2}$ 에서 $116.5 \mathrm{~mm}$ 와 $5151 \mathrm{~mm}^{2}$ 으로 방염성능기준을 만족하지 않았지만 도포량이 $300 \mathrm{~g} / \mathrm{m}^{2}$ 으로 증가함에 따라 $95.1 \mathrm{~mm}$ 와 $3694 \mathrm{~mm}^{2}$ 로 큰 폭으로 감소하여 방염성능기준을 만족하였 다. 이와 같이 방염제의 도포량이 증가함에 따라 탄화길이와 탄화면적이 감소하여 방염성능이 증가하는 경향을 나타냈으나, Table 3 에 제시된 것과 같이 잣나무 합판과 편백나무 판재에서는 그 경향이 뚜렷하지 않았다. 이는 방염제 농도 증가에 따른 침엽수종의 탄화면적이 큰 경향을 나타내지 않은 선행연구 결과와 유사한 경향을 나타내는데(Park et al., 2012), 도포처리는 목재 표면으로만 확산되기 때문에 수종 사이의 편차가 발생하는 것으로 사료된다.

본 연구에 이용된 방염제의 성능은 일반적인 상용 방염제의 도포량을 적용한 경우 소방청의 방염기준을 만족하였다. 그러나 도포량의 증가에 따른 방염성능의 향상 효과는 목재제품과 수종에 따라 차이를 나타내어 보다 다양한 목재제품과 수종에 대한 추가적인 연구가 필요한 것으로 판단된다. 타공처리된 자작나무 합판에서는 $150 \mathrm{~g} / \mathrm{m}^{2}$ 으로 처리했을 때 방염성능기준을 상회하는 것으로 나타내 방염제의 산업적 이용을 위하여 도포량 $300 \mathrm{~g} / \mathrm{m}^{2}$ 이하의 조건에서 방염성능기준을 통과하는 경제성 있는 도포량을 구명하는 연구가 필요하다.

3.2. Flame retardant performance of Betula platyphylla perforated plate treated with difference impregnation time 타공처리된 자작나무 합판에 대하여 방염제의 침지시간 차이에 따른 잔염시간, 잔신시간, 탄화길이, 탄화면적을 $45^{\circ}$ 맥켈버너 법을 이용하여 측정한 결과를 Table 4, Fig. 6에 제시하였다.

잔염시간과 잔신시간은 방염제의 침지시간과 상관없이 모두 0 초로 측정되었다. 방염제에 침지된 시간의 차이에 따른 탄화길 이와 탄화면적 측정결과, 침지처리된 모든 시험편에서 방염성능기준 $200 \mathrm{~mm}$ 와 $5000 \mathrm{~mm}^{2}$ 을 만족하였으며, 60 분의 침지시간까 지 침지시간과 방염성능은 양의 상관관계를 보였으나, 그 이후 점차 완만한 경향을 나타냈다. 90 분의 침지시간 이후 탄화길이와 탄화면적은 증가하였다. 이는 침지시간 60 분 이후 방염제가 목재에 침투하는 양이 거의 없는 것으로 판단되며, 수입 제재목의 침지시간에 따른 중량의 증가가 60분 이후에 거의 나타나지 않는 선행연구(Kim et al., 2013)와 동일한 경향을 나타냈다. 본 연구에서 자작나무 합판에 대해 수행된 침지시간에 따른 방염성능은 국산 물푸레나무, 단풍나무, 참나무의 침지처리시 30 분 이상에서 방염성능이 크게 향상된다는 선행연구(Lim et al., 2008)와 유사하였다. 그러나 소나무 시험편을 72시간 동안 침지처리한 결과 탄화길이와 탄화면적이 각각 $105.0 \mathrm{~mm}, 4750 \mathrm{~mm}^{2}$ 으로 측정되어 상대적으로 낮은 방염성능을 나타낸 선행연 구와 비교하면 수종별 최적 침지시간이 상이한 것으로 판단된다. 포플러를 $\mathrm{APP}(\mathrm{ammonium}$ polyphosphate)에 10 분 동안 침지시 
켜 난연성능을 측정한 선행연구에서 $\mathrm{APP}$ 의 분해에 의해 생성된 암모니아와 물이 가연성 물질을 희석하여 난연성능을 높여준다 는 결과를 보고한 바 있다(He, 2016). 따라서 본 연구에서 사용한 방염제의 성분 중에서 Diammonium phosphate이 열 분해되어 생성된 암모니아와 물이 타공처리된 자작나무 합판의 방염성능을 높여준 것으로 사료된다.

침지시간에 따른 타공처리된 자작나무 합판의 방염성능은 침지처리 10 분 이상에서 소방청의 방염성능기준을 만족하였으나 적절 침지시간은 60 분인 것으로 도출되었다. 또한 국내 유용 수종에 대한 최적 침지시간을 도출하기 위한 다양한 수종과 목재제 품에 대한 추가적인 연구가 필요할 것으로 판단된다.

\section{4. 결 론}

본 연구에서는 4종의 판상형 목재제품의 방염제 도포량과 침지시간에 따른 방염성능을 분석하기 위하여 소방청의 방염성능기 준에 따라 목재제품의 잔염시간, 잔신시간, 탄화길이, 탄화면적을 측정하여 다음과 같은 결론을 얻었다.

1) 도포량에 따른 방염성능시험에서 낙엽송 합판과 타공처리된 자작나무 합판는 방염제의 도포량이 증가함에 따라 탄화길이 와 탄화면적이 감소하여 방염성능이 증가하는 경향을 나타냈으나, 잣나무 합판과 편백나무 판재에서는 그 경향이 뚜렷하지 않았다.

2) 타공처리된 자작나무 합판에 대하여 방염제의 침지시간 차이에 따른 방염성능시험에서 60 분의 침지시간까지 침지시간과 방염성능은 양의 상관관계를 보였으나, 그 이후 점차 완만한 경향을 나타냈다.

본 연구를 통해서 4종의 판상형 목재제품의 방염성능에 대해서 확인하였다. 결과적으로 인계 방염제는 낙엽송 합판과 타공처리된 자작나무 합판에서 우수한 방염성능을 나타내었고, 타공처리된 자작나무 합판의 적합한 침지시간은 60 분인 것으로 확인하였다. 